\title{
Regulation of metabolism by sirtuins
}

\author{
Marcia Haigis \\ From Metabolism, diet and disease \\ Washington, DC, USA. 29-31 May 2012
}

Mitochondrial sirtuins are NAD-dependent enzymes that bind and regulate numerous metabolic pathways within the mitochondria. For example, SIRT3 functions as an NAD-dependent deacetylase that binds and activates numerous oxidative pathways. We have discovered that sirtuins regulate metabolic pathways important in tumor cell metabolism. One hallmark feature of tumor cells is a shift from oxidative to glycolytic metabolism, and this reliance on aerobic glycolysis to support cell growth is known as the Warburg effect. We have discovered that SIRT3 has an additional effect on cellular metabolism by repressing cellular glycolysis through the regulation of HIF1 $\alpha$, a transcription factor that increases gene expression of glycolytic targets. SIRT3 null cells exhibit metabolic and genetic features of the Warburg effect and enhanced tumorigenecity in vivo. Likewise, SIRT3 overexpression reduces glycolysis in tumor cells. In sum, a better understanding of sirtuinmediated regulation may identify novel ways to therapeutically target tumor metabolism.

Published: 1 June 2012

Submit your next manuscript to BioMed Central and take full advantage of:

- Convenient online submission

- Thorough peer review

- No space constraints or color figure charges

- Immediate publication on acceptance

- Inclusion in PubMed, CAS, Scopus and Google Scholar

- Research which is freely available for redistribution

\section{Biomed Central}

